\section{Effects of Particle Film Application on Leaf Gas Exchange, Water Relations, Nut Yield, and Insect Populations in Mature Pecan Trees}

\author{
Leonardo Lombardini ${ }^{1}$ \\ Texas A\&M University, Department of Horticultural Sciences, College Station, \\ TX 77843-2133
}

Marvin K. Harris ${ }^{2}$
Texas A\&M University, Department of Entomology, College Station, TX 77843-2475

D. Michael Glenn ${ }^{3}$

U.S. Department of Agriculture, Agricultural Research Service, Appalachian Fruit Research Station, Kearneysville, WV 25430

\begin{abstract}
Trials were conducted during summer months of 2002 and 2003 to evaluate the effects of a kaolin-based particle film (Surround WP, Engelhard Corp.) on gas exchange, nut quality, casebearer density and population of natural enemies (insects and arachnids) on pecan (Carya illinoinensis 'Pawnee') trees. Film application was repeated for seven (2002) or nine (2003) times during the growing season. In both years, treated trees showed lower leaf temperature (up to $4^{\circ} \mathrm{C}$ ) than untreated trees. During the warmest hours of the day, kaolin-treated leaves were generally 0 to $2^{\circ} \mathrm{C}$ cooler than air temperatures, compared to 4 to $6^{\circ} \mathrm{C}$ for control leaves. Leaf net assimilation rate, stomatal conductance and stem water potential were not affected by film application. Nut size and quality did not differ between the two treatments. Shellout (percentage of nut consisting of kernel) was not affected by treatment and averaged about 55\%. Crop grade distribution (fancy, choice, standard, and damaged) was also similar among treatments in both years. In both years, numbers of green lacewing eggs was less on kaolin-treated compared to control leaves. The density of common natural enemies (lady beetles, green lacewings, spiders) of pecan pests did not differ between treatments. The average number of developing nuts damaged by pecan nut casebearer (Acrobasis nuxvorella Neunzig) was significantly higher in kaolinsprayed trees $(\mathbf{2 4 . 2 \%})$ compared to control trees sprayed with conventional insecticides $(9.3 \%)$. The results suggest that kaolin-based particle film may not be a viable alternative to conventional methods of controlling pecan pests. Also, under adequate irrigation conditions, carbon assimilation, water relations and productivity may not benefit from kaolin particle film application.
\end{abstract}

A kaolin-based particle film technology recently has been developed as a physical barrier to repel insects and prevent disease spread (Glenn etal., 1999, 2001b). The chemically inert fine particles ( $\leq 2 \mu \mathrm{m}$ in diameter) of Surround (Engelhard Corp., Iselin, N.J.) are processed into a bright white color and disperse easily in water(Glenn etal., 1999). Thus far, research and commercial trials have shown that processedkaolin particle films can reduce damage from various insect pests (Glenn et al., 1999; Knight et al., 2000; Unruh et al., 2000); however, its

Received for publication 27 Nov. 2004. Accepted for publication $23 \mathrm{Jan}$. 2005. Use of trade name does not indicate product endorsement, nor does exclusion of a product name indicate nonendorsement. Support for this research was provided through Specific Cooperative Agreements between the USDA-ARS Appalalachian Fruit Research Station, Kearneysville, W.Va., and the Texas A\&M Univ. Dept. of Horticultural Sciences, College Station (SCA 58-1931-2-244). We thank D. Allen Dean for help in identifying the arthropods.

1'Assistant professor; e-mail 1-lombardini@tamu. edu.

${ }^{2}$ Professor

${ }^{3}$ Soil scientist.
Glenn et al. (1999) found no reduction in net photosynthetic activity in leaves of apple, pear and peach trees. Glenn et al. (2002, 2001a) also demonstrated that heat stress and solar injury were reduced when kaolin was applied to apple trees. Furthermore, kaolin induced increased leaf carbon assimilation, reduced canopy temperature and improved fruit quality characteristics (Glenn et al., 2001a).

Experiments were conducted to assess effects of kaolin particle film on pecan trees under dry, hot growing conditions that typify the pecan production regions in Texas. Leaf thermal properties, gas exchange, water relations, fruit yield and quality as well as insect pest densities were evaluated. It was hypothesized that kaolin particle film would increase leaf reflectivity, reduce leaf temperature and incidence of heat stress. It was also hypothesized that kaolin particle film would reduce insect pest pressure and lead to increases in fruit yield and quality.

\section{Materials and Methods}

Trials were conducted in 2002 and 2003 in the Texas A\&M University J. Benton Storey Pecan Experimental Orchard (lat. $30^{\circ} 31^{\prime} \mathrm{N}$, long. $96^{\circ} 24^{\prime} \mathrm{W}$, elevation $67 \mathrm{~m}$ ), located near College Station, Texas. The size of the orchard was about 3.5 ha, and the soil type was a Westwood silt loam soil, $0 \%$ to $1 \%$ slope (fine-silty, mixed, thermic Fluventic Ustochrepts). Six mature pecan trees ('Pawnee') were selected based on uniformity of size, vigor and location within the orchard. Treated trees were not directly adjacent to each other, but were surrounded by eight neighboring trees which received the same treatment applications. All trees were spaced at $10.7 \times 10.7 \mathrm{~m}$ and had $40 \pm 4 \mathrm{~cm}$ diameter trunks measured at $1.3 \mathrm{~m}$ above the ground at the beginning of the study. The selected trees and the guard trees occupied an area of about 0.7 ha.

Treatments were kaolin-based particle film and untreated controls. In both years, a 5\% $(\mathrm{w} / \mathrm{v})$ suspension of kaolin was applied using an orchard air blast sprayer. In 2002, the first application was conducted on 25 July and repeated on a weekly basis six more times during the season. In 2003, kaolin was first applied on 18 May and was followed by five weekly applications and, when good coverage was obtained, by three biweekly applications.

Each year the orchard received three urea applications (in April, May, and June) to supply a total of $168 \mathrm{~kg} \cdot \mathrm{ha}^{-1}$ of N. Zinc (Zn) was also applied three times (1, 3, and 7 weeks after green tip stage) as foliar fertilizer (NZN, $15 \mathrm{~N}-0 \mathrm{P}-0 \mathrm{~K}-5 \mathrm{Zn}$, Tessenderlo Kerley, Inc., Phoenix, Ariz.) at a rate of $475 \mathrm{~g} \cdot \mathrm{ha}^{-1}$ of $\mathrm{Zn}$ per application. In August, trees were irrigated once every 2 weeks using microsprinklers, unless natural precipitation supplied adequate water. All trees were treated with fungicides to control pecan scab (Cladosporioum caryigenum Ellis \& Langl.). Pecan nut casebearer (PNC, Acrobasis nuxvorella Neunzig) and hickory shuckworm (Cydia caryana Fitch) also were controlled using conventional pesticides, except for those trees used for the PNC 
infestation experiment (see later). Due to the alternate bearing habit of pecan, the second year of the investigation was characterized by heavier crop load so crop thinning (shaking the trunk and/or or main branches for 3 to $5 \mathrm{~s}$ ) was performed in mid-July to prevent overcropping. The thinning procedure resulted in removal of about $30 \%$ of the crop from each tree.

Kaolin residue. Particle density on the adaxial and abaxial leaf surface was measured three times per season by washing off each leaf surface from twenty leaves per tree with deionized water into separate, preweighed beakers. Beakers were then placed in oven at $75^{\circ} \mathrm{C}$ for $24 \mathrm{~h}$ to allow the water to evaporate and reweighed. The leaf area of the same twenty leaves per tree was determined with a leaf area meter connected with a transparent belt conveyor (LI-3000A and LI-3050A; respectively, LI-COR, Lincoln, Nebr.). Average surface area density of the particle film was calculated by dividing the weight of the particle film collected from each leaf surface by the leaf area of the same surface.

Canopy light interception and leaftemperature. To measure if the amount of solar radiation scattered by the particle film increased inside the treated canopies, photosynthetic photon flux density $(P P F D)$ and air temperature $\left(\mathrm{T}_{\mathrm{a}}\right)$ were measured on one tree per treatment. In both years, $P P F D$ data were collected by quantum sensors (LI190SB-L, LI-COR, Lincoln, Nebr.) and $T_{a}$ was measured using radiation-shielded thermocouples $(\mathrm{Cu}-\mathrm{Co}$; Omega Engineering Inc., Stamford, Conn.). Leaf temperature $\left(T_{1}\right)$ was also measured with similar thermocouples attached to the abaxial side of three leaves/tree using lightweight clips. Measurement leaves were fully expanded and selected from exterior south-facing canopy positions at approximately $3 \mathrm{~m}$ from the ground (lower third of the canopy). All quantum sensors and thermocouples were connected to a data logger (CR10X; Campbell Scientific, Logan, Utah), and data were collected using at 1-s interval and stored as 10-min averages. After data from the first two trees were collected for 5 to $7 \mathrm{~d}$, all sensors were moved to the next pair of trees until all six trees were measured.

Leaf chlorophyll content. SPAD readings were collected three times in 2002 using a chlorophyll meter (SPAD-502; Minolta, Ramsey, N.J.). Before measurements, control and treated leaves were washed using distilled water to prevent any possible interference of the particle film with the SPAD readings.

Gas exchange. Leaf net $\mathrm{CO}_{2}$ assimilation rate $(\mathrm{A})$, transpiration rate $(\mathrm{E})$, and stomatal conductance $\left(\mathrm{g}_{\mathrm{s}}\right)$ were determined using an infrared gas analysis system (LI-6400; LI-COR Inc., Lincoln, Nebr.). Single leafmeasurements were taken at a chamber air $\mathrm{CO}_{2}$ concentration of $360 \mu \mathrm{L} \cdot \mathrm{L}^{-1}$ and a $1500 \mu \mathrm{mol} \cdot \mathrm{m}^{-2} \cdot \mathrm{s}^{-1}$ irradiance, supplied by a red/blue light source (6400-02B; LI-COR Inc., Lincoln, Nebr.) on the adaxial leaf surface. At each measurement time, three fully expanded terminal leaves were selected per tree and the middle leaflets were used for measurements. Gas exchange was measured between 1000 and $1400 \mathrm{HR}$ on
5 and 19 Aug.; 2, 16, and 23 Sept. 2002; 2, 16, and 30 June; 14 and 28 July; 11 and 25 Aug.; and 8 Sept. 2003.

Carbon-13 isotopic discrimination. Three $15-\mathrm{cm}$-long twigs per tree were collected from the previous season shoots in January 2003. The twigs were debudded, cut in 2 to $3 \mathrm{~cm}$ long sections, dried at $70^{\circ} \mathrm{C}$ for $72 \mathrm{~h}$, ground to pass through a 40-mesh screen on the Wiley Milland analyzed for ${ }^{13} \mathrm{C}$ content and ${ }^{13} \mathrm{C}$ discrimination $(\Delta)$ by Isotope Services (Los Alamos, N.M.) as described by Glenn et al. (2003).

Stem water potential. The leaves used for gas exchange measurements were used immediately to determine midday stem water potential $(\psi)$ with a Scholander-type pressure chamber (Soil Moisture Equipment Corp., Santa Barbara, Calif.). Measurements were collected between 1200 and 1300 HR according to the procedure described by McCutchan and Shackel (1992).

Density of natural enemies and common pecan pests. In both years, density of three important groups of natural enemies (lady beetles, green lacewings, and spiders) of pecan pests was monitored on treated and control trees throughout the course of the experiment using a refuge banding technique. Single-face corrugated cardboard was cut in pieces (bands) $5 \times 10 \mathrm{~cm}$ in size. Bands were wrapped around 1-year-old terminal shoots and kept in place by clothespins. Bands were deployed immediately after kaolin application and removed before the following application. Bands were taken to the laboratory and placed in a freezer $\left(-20^{\circ} \mathrm{C}\right)$ for at least $24 \mathrm{~h}$ to kill all insects and arthropods, which were subsequently counted and identified. In 2003, ten leaves on sides facing each of the four cardinal directions of the lower third of the canopy were selected and pecan pests and natural enemies present were identified and recorded. The insects identified were black-margined aphids (BMA, Monellia caryella Fitch) at the nymph (NY) and adult (AD) stages, adult yellow pecan aphids (YPA, Monelliopsis pecanis Bissell), lacewings [hatched eggs (HE), nonhatched eggs (NHE), larvae (LA), pupae (PU), and AD), and lady beetles (LA, PU, and AD]. Spiders [egg sacks (ES), immature (IM), and AD] were also identified and recorded.

Infestation of pecan nut casebearer. In 2003, the effectiveness of kaolin in controlling PNC was tested as an alternative to conventional pesticide application. Six additional trees were selected from the same orchard and received
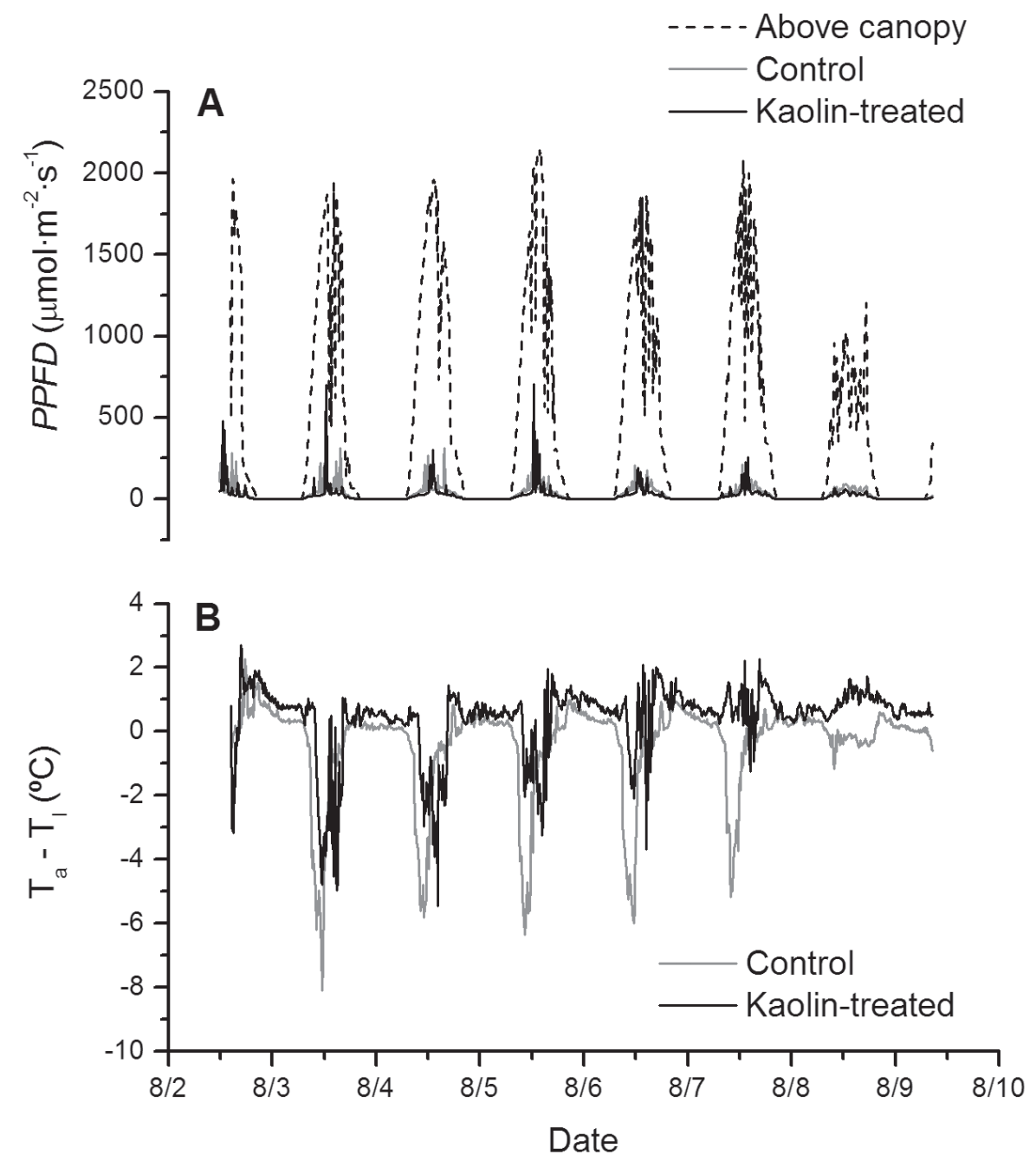

Fig. 1. Representative hourly average photosynthetic photon flux density $(P P F D)(\mathbf{A})$ measured in 2002 at the top of, or inside, the canopy and leaf-air temperature differences $\left(\mathrm{T}_{\mathrm{a}}-\mathrm{T}_{1}\right)(\mathbf{B})$ for 'Pawnee' pecan trees sprayed with a 5\% Surround particle film suspension. Each line reports data collected on one tree. 
the kaolin and control treatments as in the main experiment, with the difference that insecticides were not used in the first part of the season to control PNC. The incidence of PNC was estimated by counting the percentage of developing fruit showing typical frass and webbing caused by PNC larvae. Percentage damage was calculated on total number of fruit present in 30 clusters per tree, chosen in the lower third of the canopy. Data were collected on 29 May and 3 June, with 1157 and 1039 evaluated fruit, respectively counted on the two dates.

Yield and nut quality. Fruit were harvested in early October and total yield per tree was determined. About $400 \mathrm{~g}$ of nuts from each tree were utilized to evaluate in-shell and kernel quality characteristics. In-shell characteristics were determined based on exterior appearance of the nut. Nuts graded as excellent did not show

any visible defect. Cracked nuts had evident cracks in the shell which usually lead to rapid deterioration of the kernel quality. Split nuts were those with evident gap between the two halves, which sometimes are a consequence of premature germination (sprouted nuts). Sticktights indicate those immature fruit that did not open properly, i.e., the shuck dried out before dehiscing. Nuts exhibiting the typical scarring caused by hickory shuckworm were recorded. Kernels characteristics and percentage of nut consisting of kernel (shellout) were evaluated after all sample nuts were cracked and shells were carefully separated from the meat. Kernel quality was graded into five classes: fancy (sound kernels with no defects and a golden color), choice (sound kernels with no defects and light-brown color), standard (kernels with minor defects and golden color), and damaged (inedible kernels). Among

Table 1. SPAD readings and ${ }^{13} \mathrm{C}$ discrimination measured on leaves of 'Pawnee' pecan tree sprayed with kaolin-based particle film.

\begin{tabular}{lcccc}
\hline & \multicolumn{3}{c}{ SPAD } & Isotopic ${ }^{13}$ C discrimination \\
\cline { 2 - 5 } Treatment & Aug. 1 & Aug. 23 & Sep. 16 & $(\Delta)$ \\
\hline Control & $46.2 \mathrm{a}^{\mathrm{z}}$ & $47.1 \mathrm{a}$ & $46.0 \mathrm{a}$ & $22.3 \mathrm{a}$ \\
Kaolin & $50.4 \mathrm{a}$ & $52.3 \mathrm{~b}$ & $49.1 \mathrm{~b}$ & $21.7 \mathrm{a}$ \\
\hline
\end{tabular}

${ }^{\mathrm{z}}$ Mean separation by $t$ test $(P=0.05)$.

Table 2. List of the taxa of spiders and insects captured on pecan trees in 2003 using a banding technique.

\begin{tabular}{|c|c|}
\hline Spiders (Family, species) & Insects (Order, Family) \\
\hline Anyphaenidae & Coleoptera \\
\hline Hibana sp. & Elateridae \\
\hline Clubionidae & Hemiptera \\
\hline Clubiona sp. & Miridae \\
\hline unidentified & Anthocoridae \\
\hline Corinnidae & Homoptera \\
\hline Trachelas mexicanus & unidentified \\
\hline unidentified & Hymenoptera \\
\hline Gnaphosidae & Formicidae \\
\hline Cesonia sp. & unidentified \\
\hline Herpyllus ecclesiasticus & Lepidoptera \\
\hline Nodocion floridanus & unidentified \\
\hline unidentified & Neuroptera \\
\hline Linyphiidae & unidentified \\
\hline unidentified & Orthoptera \\
\hline Philodromidae & unidentified \\
\hline Philodromus sp. & Psocoptera \\
\hline Salticidae & unidentified \\
\hline Eris militaris & \\
\hline Eris sp. & \\
\hline Hentzia palmarum & \\
\hline Hentzia sp. & \\
\hline Pelegrina sp. & \\
\hline Phidippus audax & \\
\hline Phidippus sp. & \\
\hline Thiodina sp. & \\
\hline unidentified & \\
\hline Theridiidae & \\
\hline unidentified & \\
\hline Thomisidae & \\
\hline Xysticus sp. & \\
\hline
\end{tabular}

the damaged kernels, were those exhibiting the typical black, rounded spots classified as stink bug-damaged (Euschistus servus Say, Chlorochroa ligata Say, Acrosternum hilare Say, and Nezara viridula Linnaeus).

Experimental design and statistical analysis. The experimental design was a completely randomized design with three single-tree replications per treatment. For the evaluation of PNC infestation, the insecticide $\times$ kaolin interaction was considered. Data were subjected to analysis of variance (ANOVA) and where applicable means were separated using Fisher's least significance difference (LSD) at $P \leq 0.05$ using SAS software (SAS Institute Inc., Cary, N.C.).

\section{Results}

Kaolin density. Following each application, the average surface area density of kaolin was $527 \pm 23 \mu \mathrm{g} \cdot \mathrm{cm}^{-2}$ and $450 \pm 30 \mu \mathrm{g} \cdot \mathrm{cm}^{-2}$ for adaxial and abaxial leaf surfaces, respectively. Kaolin was not detected on control leaves.

Canopy light interception and leaf temperature. PPFD and temperature data at the experimental site were similar in both years. Representative data from cloudless measurement periods in 2002 are shown in Fig. 1.PPFD values measured inside the canopy of treated and untreated trees were always $10 \%$ to $20 \%$ of those in full sunlight (Fig. 1A). Frequently $P P F D$ values inside kaolin-treated canopies were higher than those measured inside control trees (Fig. 1A). In both years, kaolin-sprayed trees frequently showed lower $\mathrm{T}_{1}$ (up to $4{ }^{\circ} \mathrm{C}$ ) than control trees. Consequently, the difference $\left(\mathrm{T}_{\mathrm{a}}-\mathrm{T}_{1}\right)$ measured in sun-exposed leaves during the warmest hours of the day was 0 to $2{ }^{\circ} \mathrm{C}$ in treated leaves versus 4 to $6{ }^{\circ} \mathrm{C}$ measured in control leaves (Fig. 1B).

Leaf chlorophyll content. The effects of the particle film on leaf chlorophyll concentration varied depending on the time after the first treatment. One week after the first treatment, there were no differences in leaf chlorophyll concentration between kaolin-treated and control leaves. However, 4 weeks (23 Aug.) after the first treatment, leaf chlorophyll concentration was $11 \%$ higher in kaolin-treated leaves $(P=0.01)$ than control leaves (Table 1). Such differences were maintained after seven weeks (Sept. 16) after the first application $(P=0.02)$.

Gas exchange. In both years, A and $g_{\mathrm{s}}$ values were similar throughout the growing season. In 2002, A averaged 8.6 and $7.7 \mu \mathrm{mol} \cdot \mathrm{m}^{-2} \cdot \mathrm{s}^{-1}$ in control and kaolin-treated leaves, respectively. In 2003 , A was $10.0 \mu \mathrm{mol} \cdot \mathrm{m}^{-2} \cdot \mathrm{s}^{-1}$ in control leaves and $10.3 \mu \mathrm{mol} \cdot \mathrm{m}^{-2} \cdot \mathrm{s}^{-1}$ in treated leaves.

Table 3. Populations of natural enemies captured on canopies of pecan trees treated with kaolin-based particle film. Numbers are averages of the total number of enemies counted in 2003 on 10 bands per tree.

\begin{tabular}{|c|c|c|c|c|c|c|c|c|c|c|}
\hline Treatment & 16 June & 23 June & 30 June & 7 July & 15 July & 24 July & 5 Aug. & 12 Aug. & 18 Aug. & 11 Sept. \\
\hline \multicolumn{11}{|c|}{ Number of spiders } \\
\hline Kaolin & $3.7 \mathrm{a}$ & $2.6 \mathrm{a}$ & $0.3 \mathrm{~b}$ & $2.7 \mathrm{a}$ & $2.0 \mathrm{~b}$ & $1.0 \mathrm{~b}$ & $3.0 \mathrm{~b}$ & $5.3 \mathrm{a}$ & $5.3 \mathrm{~b}$ & $2.0 \mathrm{a}$ \\
\hline \multicolumn{11}{|c|}{ Number of lacewings } \\
\hline Kaolin & $0.0 \mathrm{a}$ & $0.0 \mathrm{a}$ & $0.2 \mathrm{~b}$ & $0.3 \mathrm{a}$ & $0.0 \mathrm{a}$ & $0.0 \mathrm{a}$ & $0.0 \mathrm{a}$ & $1.7 \mathrm{a}$ & $0.0 \mathrm{a}$ & $0.0 \mathrm{a}$ \\
\hline
\end{tabular}

${ }^{2}$ Mean separation by $t$ test $(P=0.05)$. 
Table 4. Density of natural enemies and common pecan pests observed in 2003 on the abaxial surface of pecan leaves treated with kaolin-based particle film. Data were obtained from 40 leaves per tree per treatment. BMA = black-margined aphid, YPA = yellow pecan aphid, LW= lacewings, NY= nymph stage, $\mathrm{AD}=$ adult stage, $\mathrm{HE}=$ hatched eggs, $\mathrm{NHE}=$ nonhatched eggs, $\mathrm{LA}=$ larvae, $\mathrm{PU}=$ pupae, $\mathrm{ES}=\mathrm{egg}$ sacks, $\mathrm{IM}=\mathrm{immature}$.

\begin{tabular}{|c|c|c|c|c|c|c|c|c|c|c|c|c|}
\hline \multirow[b]{2}{*}{ Date } & \multirow[b]{2}{*}{ Treatment } & \multicolumn{2}{|c|}{ BMA } & \multicolumn{2}{|c|}{ YPA } & \multicolumn{2}{|c|}{ LW } & \multicolumn{5}{|c|}{ Spiders } \\
\hline & & NY & $\mathrm{AD}$ & $\mathrm{AD}$ & $\mathrm{HE}$ & $\mathrm{ENH}$ & LAR & PUP & $\mathrm{AD}$ & ES & IM & $\mathrm{AD}$ \\
\hline \multirow[t]{2}{*}{16 June } & Control & 0 & 0 & 0 & $0.7 \mathrm{a}^{\mathrm{z}}$ & $0.3 \mathrm{a}$ & 0 & 0 & 0 & 0 & 0 & $1.0 \mathrm{a}$ \\
\hline & Kaolin & 0 & 0 & 0 & $0.7 \mathrm{a}$ & $0.3 \mathrm{a}$ & 0 & 0 & 0 & 0 & 0 & $0.3 \mathrm{~b}$ \\
\hline \multirow[t]{2}{*}{23 June } & Control & 0 & 0 & $2.0 \mathrm{a}$ & $7.0 \mathrm{a}$ & $3.3 \mathrm{a}$ & 0 & 0 & $1.0 \mathrm{a}$ & 0 & 0 & 0 \\
\hline & Kaolin & 0 & 0 & $2.0 \mathrm{a}$ & $2.0 \mathrm{~b}$ & $0.7 \mathrm{~b}$ & 0 & 0 & $0.7 \mathrm{a}$ & 0 & 0 & 0 \\
\hline \multirow[t]{2}{*}{30 June } & Control & 0 & 0 & $2.0 \mathrm{a}$ & $10.0 \mathrm{a}$ & $3.0 \mathrm{a}$ & 0 & 0 & 0 & 0 & 0 & 0 \\
\hline & Kaolin & 0 & 0 & $0 \mathrm{~b}$ & $2.3 \mathrm{~b}$ & $0.7 \mathrm{~b}$ & 0 & 0 & 0 & 0 & 0 & 0 \\
\hline \multirow[t]{2}{*}{7 July } & Control & 0 & 0 & $0.7 \mathrm{a}$ & $6.3 \mathrm{a}$ & $2.3 \mathrm{a}$ & 0 & 0 & 0 & 0 & $0.3 \mathrm{a}$ & 0 \\
\hline & Kaolin & 0 & 0 & $0.7 \mathrm{a}$ & $0.7 \mathrm{~b}$ & $0.3 \mathrm{~b}$ & 0 & 0 & 0 & 0 & $0.3 \mathrm{a}$ & 0 \\
\hline
\end{tabular}

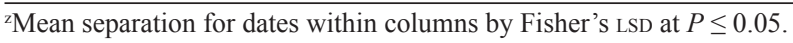

Table 5. Percent of developing pecan fruit damaged by pecan nut casebearer (Acrobasis nuxvorella Neunzig) after the application of conventional pesticide, kaolin-based particle film, or a combination of both. Data were obtained in 2003 by checking all fruit present in 30 terminal clusters per tree.

\begin{tabular}{lrr}
\hline & \multicolumn{2}{c}{$\begin{array}{c}\text { Damaged nuts } \\
\text { (\% nuts) }\end{array}$} \\
\cline { 2 - 3 } Treatment & 29 May & 5 June \\
\hline Pesticide, no kaolin & $9.3 \mathrm{~b}^{\mathrm{z}}$ & $6.2 \mathrm{a}$ \\
Pesticide + kaolin & $13.8 \mathrm{~b}$ & $12.1 \mathrm{a}$ \\
No pesticide, no kaolin & $29.9 \mathrm{a}$ & $14.8 \mathrm{a}$ \\
No pesticide + kaolin & $24.2 \mathrm{a}$ & $10.3 \mathrm{a}$ \\
\hline${ }^{ }$Mean separation within columns by Fisher's LSD \\
at $P \leq 0.05$.
\end{tabular}

E of kaolin-treated leaves was significantly lower than that of control leaves on two dates in 2002 (13 and 20 Aug., data not shown) and on one date in 2003 (28 July, data not shown). Carbon isotope discrimination was not altered by particle film treatment (Table 1).

Stem water potential. Midday $\psi$ was not affected by the particle film treatment on any of the measurement dates (data not shown). In 2002, average seasonal $\psi$ was $-1.0 \mathrm{MPa}$ for both treatments. In 2003, $\psi$ in kaolin-sprayed trees was significantly higher than in control trees only on 30 June $(-1.1 \mathrm{MPa}$ and $-1.3 \mathrm{MPa}$, respectively). In 2003, seasonal average in the two treatments was identical $(-1.2 \mathrm{MPa})$.

Density of natural enemies and common pecan pests. Spiders from as many as nine families and insects from eight different orders were captured with the banding technique (Table 2). Although the list is not comprehensive, the banding technique was an efficient way to monitor the presence of a considerable number of insects and other natural enemies. In 2002, the number of natural enemies (spiders and lacewings) captured in the cardboard bands was not affected by the presence of kaolin on the leaves and stems (data not presented). In 2003, differences were observed on five out of ten dates for spiders, and on two out of ten dates for lacewings, and generally there were fewer on kaolin treated trees (Table 3). However, almost every time that differences were detected, the smaller number of lacewings was captured from kaolin-sprayed trees. The only exception was recorded on 12 Aug., when the number of lacewings was actually greater on kaolin-sprayed trees. Visual monitoring performed weekly confirmed that fewer lacewings were present on sprayed trees throughout the season (Table 4). Visual monitoring data indicated that the kaolin was occasionally a mechanical barrier not only for natural enemies, but also for some common pecan pests such as yellow pecan aphids (Table 4). Lady beetles of any developmental stage were not detected by visual monitoring.

Infestation of pecan nut casebearer. The first PNC damage assessment (29 May 2003) revealed that when neither pesticide nor kaolin was used, about $30 \%$ of the counted fruit showed the typical exit holes and frass caused by PNC larvae (Table 5). The sole application of kaolin was not an effective way to control PNC, and the amount of PNC-damaged fruit $(24.2 \%)$ was not significantly different than the amount detected on trees that did not receive kaolin. The ineffectiveness of kaolin in reducing PNC infestation was also illustrated when the film was used in conjunction with the pesticide. While the conventional pesticide decreased the amount of PNC-damaged fruit $(9.3 \%)$, when kaolin and pesticide were applied together there was not any additional beneficial effect in protecting more fruit $(13.8 \%$ of damaged fruit) (Table 5). The lower numbers indicated in the second damage assessment (June 5) are the result of the fruit drop-off caused by the PNC larvae.

Yield and nut quality. There were not statistically significant differences in the yield between the two treatments in either year. In 2002 , which was an "off" year for pecan production, average yield per tree was similar in the two treatments with 7.4 and $8.5 \mathrm{~kg}$ in control and kaolin-treated trees, respectively. In 2003, an "on" year, yield was approximately double that of the previous year with $14.3 \mathrm{~kg} /$ tree in control trees and $16.2 \mathrm{~kg} /$ tree in kaolin-treated trees, respectively (Table 6). In-shell characteristics (percent of excellent, cracked, split, sprouted, sticktights and shuckworm-damaged nuts) of the nuts were also equal in the two treatments in the 2 years (2002 data not presented; 2003 data in Table 6). Shellout and all other kernel characteristics investigated were also not significantly different between treatments in neither in 2002 (data not presented) or 2003 (Table 7).

\section{Discussion}

Our data indicated that kaolin reduced leaf temperature and increased the amount of light reaching the interior parts of the canopy. Similar effects have been reported for other fruit tree crops such as apples, grapes and citrus (Glenn et al., 2003, 2001a; Jifon and Syvertsen, 2003). Although not verified in the present study, the mechanism for reduced leaf temperature is thought to be increased reflectivity from the treated leaf surfaces. Increased leaf reflectance would reduce the amount of radiant energy absorbed by sunlit leaves, and moderate leaf temperature. A reduction in leaf temperature would be expected to result in reduced leaf-air vapor pressure deficit (LAVPD) and increased $g_{s}$ and $A$ as has been shown for other tree species (Glenn et al., 2003; Jifon and Syvertsen, 2003).

While the application of dusts and other particulates has been shown to impair photosynthetic activity (Armbrust, 1986; Krishnamurthy and Rajachidambaram, 1986; LeBoeuf, 2000; Thompson et al., 1984; Vardaka et al., 1995), previous studies reported that kaolin can stimulate net assimilation rate (Glenn etal., 2003, 2001a; Jifon and Syvertsen, 2003). In the present study, no effect of kaolin particle film sprays on $\mathrm{g}_{\mathrm{s}}$ or A was observed, even though leaftemperature was significantly reduced by kaolin spray. On a few occasions, A and $g_{s}$ of kaolin treated leaves were lower than those of control non-treated leaves (data not shown). These results may indicate the insensitivity of $g_{s}$ and A of pecan leaves to changes in leaf temperature and LAVPD. The trees used in the present study were adequately irrigated and fertilized. Pecan trees have been classified as water-spenders, with young trees capable of transpiring 3 to $4 \mathrm{~L} \cdot \mathrm{d}^{-1}$ and mature trees requiring as much as 500 to $1000 \mathrm{~L} \cdot \mathrm{d}^{-1}$

Table 6. In-shell characteristics (2003 harvest) of pecan nuts following a season-long application of kaolin-based particle film.

\begin{tabular}{|c|c|c|c|c|c|c|c|c|}
\hline Treatment & $\begin{array}{c}\text { Yield } \\
\text { (kg/tree) }\end{array}$ & $\begin{array}{l}\text { Nut size } \\
\text { (nuts/kg) }\end{array}$ & $\begin{array}{c}\text { Excellent nuts } \\
\qquad(\%)\end{array}$ & $\begin{array}{c}\text { Cracked nuts } \\
(\%)\end{array}$ & $\begin{array}{l}\text { Split nuts } \\
(\%)\end{array}$ & $\begin{array}{l}\text { Sprouted nuts } \\
(\%)\end{array}$ & $\begin{array}{c}\text { Sticktights } \\
(\%)\end{array}$ & $\begin{array}{c}\mathrm{SW}^{\mathrm{z}} \text {-damaged nuts } \\
(\%)\end{array}$ \\
\hline Control & $14.3 \mathrm{a}^{\mathrm{y}}$ & $119 \mathrm{a}$ & $98.6 \mathrm{a}$ & $1.0 \mathrm{a}$ & $0.4 \mathrm{a}$ & $0 \mathrm{a}$ & $0 \mathrm{a}$ & $0 \mathrm{a}$ \\
\hline Kaolin & $16.2 \mathrm{a}$ & $122 \mathrm{a}$ & $99.2 \mathrm{a}$ & $0.8 \mathrm{a}$ & $0.0 \mathrm{a}$ & $0 \mathrm{a}$ & $0 \mathrm{a}$ & $0 \mathrm{a}$ \\
\hline
\end{tabular}

${ }^{\mathrm{z}} \mathrm{SW}=$ hickory shuckworm.

${ }^{\mathrm{y}}$ Mean separation by $t$ test $(P=0.05)$. 
Table 7. Characteristics of pecan kernels following a season-long application of kaolin-based particle film. Data refer to 2003 harvest.

\begin{tabular}{lcccccc}
\hline Treatment & $\begin{array}{c}\text { Shellout } \\
(\%)\end{array}$ & $\begin{array}{c}\text { Fancy nuts } \\
(\%)\end{array}$ & $\begin{array}{c}\text { Choice nuts } \\
(\%)\end{array}$ & $\begin{array}{c}\text { Standard nuts } \\
(\%)\end{array}$ & $\begin{array}{c}\text { Damaged nuts } \\
(\%)\end{array}$ & $\begin{array}{c}\mathrm{SB}^{\mathrm{z}} \text {-damaged nuts } \\
(\%)\end{array}$ \\
\hline Control & $54.2 \mathrm{a}^{\mathrm{y}}$ & $6.1 \mathrm{a}$ & $21.8 \mathrm{a}$ & $40.6 \mathrm{a}$ & $25.5 \mathrm{a}$ & $6.0 \mathrm{a}$ \\
Kaolin & $55.5 \mathrm{a}$ & $8.3 \mathrm{a}$ & $27.9 \mathrm{a}$ & $41.7 \mathrm{a}$ & $18.4 \mathrm{a}$ & $3.7 \mathrm{a}$ \\
\hline
\end{tabular}

${ }^{\mathrm{z}} \mathrm{SB}=$ stink bug.

${ }^{\mathrm{y}}$ Mean separation by $t$ test $(P=0.05)$.

(Sammis and Herrera, 1999). However, with sufficient water supply, pecan trees have been shown to maintain high $g_{s}$ and $A$, even in conditions of elevated temperatures and LAVPD (Andersen and Brodbeck, 1988). High temperature $\left(41.5^{\circ} \mathrm{C}\right)$ stress did not significantly affect gas exchange rates of pecan leaves exposed to full sunlight $\left(2000 \mu \mathrm{mol} \cdot \mathrm{m}^{-2} \cdot \mathrm{s}^{-1}\right)$ and $3 \mathrm{kPa}$ LAVPD (Andersen and Brodbeck, 1988). This insensitivity of pecan stomata to high temperature and LAVPD is perhaps responsible for the unusually high $\mathrm{A}$ and $\mathrm{g}_{\mathrm{s}}$ when compared to other temperate fruit trees (Hall et al., 1975; Khairi and Hall, 1976; Kriedemann, 1971). The high water requirement for pecan physiology, growth and productivity, and the observed insensitivity of its stomata to LAVPD is also reflected in the rather high season-long ${ }^{13} \mathrm{C}$ discrimination values $(21 \%$ to $22 \%$ ). These values lie in the upper end of the range of typical $\Delta$ values for $\mathrm{C}_{3}$ species $(15 \%$ to $28 \%$; Griffith, 1993) and suggest a low water use efficiency for this species.

All parameters collected lead to the conclusion that kaolin particle film did not have detectable beneficial effects on the physiology and productivity of pecan trees, as it has been reported for temperate crops such as apple and grapes (Glenn et al., 2003, 2001a; Jifon and Syvertsen, 2003).

The kaolin application was not an effective method to reduce the population of some common pecan pests, such as casebearer and yellow pecan aphids. In most cases, insects and spiders, which act as natural enemies for pecan pests, were also not affected; although, on some dates, the numbers of lacewing eggs and spiders were smaller in kaolin-treated leaves.

Application of kaolin particle films on mature pecan tree canopies resulted in a reduction of leaf temperatures. However, E, $\mathrm{g}_{\mathrm{s}}$ and $\mathrm{A}$, pest control, yield, shellout, in-shell and kernel characteristics of harvested pecans were not affected by kaolin particle film treatment. This indicates that surface effects of kaolin spray on pecan are not as critical as they are in apples and citrus. The benefits of kaolin that have been demonstrated in other fruit crops did not show on the size and age of pecan trees growing under the conditions of this study. Further studies may be required to determine whether kaolin could be beneficial during periods of potential water stress as under deficit irrigation conditions designed to conserve water.

\section{Literature cited}

Andersen, P.C. and B.V. Brodbeck. 1988. $\mathrm{Net} \mathrm{CO}_{2}$ assimilation and plant water relations characteristics of pecan growth flushes. J. Amer. Soc. Hort. Sci. 113:444-450.

Armbrust, D.V. 1986. Effect of particulates (dust) on cotton growth, photosynthesis, and respiration. Agron. J. 78:1078-1081.

Farmer, A.M. 1993. The effects of dust on vegetation-A review. Environ. Pollut. 79:63-75.

Glenn, D.M.,A. Erez, G.J. Puterka, and P. Gundrum. 2003. Particle films affect carbon assimilation and yield in 'Empire' apple. J. Amer. Soc. Hort. Sci. 128:356-362.

Glenn, D.M., E. Prado, A. Erez, J.R. McFerson, and G.J.Puterka.2002.Areflective, processed-kaolin particle film affects fruit temperature, radiation reflection, and solar injury in apple. J. Amer. Soc. Hort. Sci. 127:188-193.

Glenn, D.M., G.J. Puterka, S.R. Drake, T.R. Unruh, A.L. Knight, P. Baherie, E. Prado, and T.A. Baugher. 2001a. Particle film application influences apple leaf physiology, fruit yield, and fruit quality. J. Amer. Soc. Hort. Sci. 126:175-181.

Glenn, D.M., G.J. Puterka, T. Vanderzwet, R.E. Byers, and C. Feldhake. 1999. Hydrophobic particle films: a new paradigm for suppression of arthropod pests and plant diseases. J. Econ. Entomol. 92:759-771.

Glenn, D.M., T. van der Zwet, G.J. Puterka, P. Gundrum, and E. Brown. 2001b. Efficacy of kaolin-based particle films to control apple diseases. Plant Health Prog. 23 Aug. 2001. $\mathrm{http}: / / \mathrm{www}$.planthealthprogress.org/current/re- search/particle/article.htm.

Griffith, H. 1993. Carbon isotope discrimination, $\mathrm{p}$. 181-192. In: D.O. Hall, J.M.O. Scurlock, H.R. Bolhar-Nordenkampf, R.C. Leegood, and S.P. Long (eds.). Photosynthesis and production in a changing environment: A field and laboratory manual. Chapman \& Hall, New York.

Hall, A.E., S.E. Camacho-B, and M.R. Kaufmann. 1975. Regulation of water loss by citrus leaves. Physiol. Plant. 33:62-65.

Jifon, J.L. and J.P. Syvertsen. 2003. Kaolin particle film applications can increase photosynthesis and water use efficiency of 'Ruby Red' grapefruit leaves. J. Amer. Soc. Hort. Sci. 128:107-112.

Khairi, M.M.A. and A.E. Hall. 1976. Temperature and humidity effects on net photosynthesis and transpiration of citrus. Physiol. Plant. 36:29-34.

Knight, A.L., T.R. Unruh, B.A. Christianson, G.J. Puterka, and D.M. Glenn. 2000. Effects of a kaolin-based particle film on obliquebanded leafroller (Lepidoptera: Tortricidae). J. Econ. Entomol. 93:744-749.

Kriedemann, P.E. 1971. Photosynthesis and transpiration as a function of gaseous diffusive resistances in orange leaves. Physiol. Plant. 24:218-225.

Krishnamurthy, K.V. and C. Rajachidambaram. 1986. Factors associated with reduction in photosynthetic oxygen evolution in cement dust coated leaves. Photosynthetica 20:164-168.

LeBoeuf, J. 2000. Practical applications of remote sensing technology - An industry perspective. HortTechnology 10:475-480.

McBride, J. 2000. Whitewashing agriculture. Agr. Res. 48:14-17.

McCutchan, H. and K.A. Shackel. 1992. Stem-water potential as a sensitive indicator of water stress in prune trees (Prunus domestica L. cv. French). J. Amer. Soc. Hort. Sci. 117:607-611.

Sammis, T. and E.A. Herrera. 1999. Estimating water needs for pecan trees. New Mexico State Univ. Coop. Ext. Serv. 11 Nov. 2002. http://www.cahe. nmsu.edu/pubs/ h/h-636.html.

Thompson, J.R., P.W. Mueller, W. Fluckiger, and A.J. Rutter. 1984. The effect of dust on photosynthesis and its significance for roadside plants. Environ. Pollut. 34:171-190.

Unruh, T.R.,A.L. Knight, J. Upton, D.M. Glenn, and G.J.Puterka. 2000. Particle films for suppression of the codling moth (Lepidoptera: Tortricidae) in apple and pear orchards. J. Econ. Entomol. 93:737-743.

Vardaka, E., C.M. Cook, T. Lanaras, S.P. Sgardelis, and J.D. Pantis. 1995. Effect of dust from a limestone quarry on the photosynthesis of Quercus coccifera, an evergreen schlerophyllous shrub. Bul. Environ. Contam. Toxicol. 54:414-419.

Werblow, S. 1999. Favorable film. Ore. FarmerStockman (April):8-10. 